5. Про добровільне об'єднання територіальних громад : Закон України від 5 лютого 2015 року № 157-VIII. URL: https://zakon.rada.gov.ua/ laws/main/ 157-VIII (дата звернення: 15.04.2021).

6. Про співробітництво територіальних громад : Закон України від 17 червня 2014 року № 1508-VII. URL : https://zakon.rada.gov.ua/ laws/main/1508-18 (дата звернення: 15.04.2021).

7. Про Стратегію сталого розвитку «Україна - 2020»: указ Президента України від 12 січня 2015 року № 5/2015. URL: https://zakon.rada.gov.ua/ laws/show/5/2015 (дата звернення: 15.04.2021).

8. Про схвалення Концепції реформування місцевого самоврядування та територіальної організації влади в Україні : розпорядження Кабінету Міністрів України від 1 квітня 2014 року № 333-р. URL: https://zakon.rada.gov.ua/laws/main/333-2014-\%D1\%80 (дата звернення: 15.04.2021).

DOI https://doi.org/10.30525/978-9934-26-074-2-2

\title{
ДЕЯКІ ТЕОРЕТИЧНІ \\ ТА ПРАКТИЧНІ АСПЕКТИ РОЗВИТКУ ПРАВОВОЇ ОСВІТИ
}

\author{
Голубєва В. О. \\ кандидат юридичних наук, професор, \\ професор кафедри міжнародного та європейського права \\ ДВНЗ «Київський національний економічний університет \\ імені Вадима Гетьмана» \\ м. Київ, Україна \\ Голубєва А. О. \\ магістр правознавства, магістр міжнародного права, \\ адвокат \\ м. Київ, Україна
}

В сучасних умовах глобалізації, взаємозалежності світу, науковотехнічного прогресу, проникненню технологій в різні сфери життя, освіта (в т. ч. правова) стає одним 3 ключових факторів розвитку/прогресу, а умови та право на освіту, розглядаються важливими умовами існування й реалізації інших прав людини (зокрема, економічних, соціальних, культурних, громадянських і політичних). В сучасних умовах незаперечною $є$ теза, що освіта (будь-якого рівня, 14 
у т. ч. й вища) є невід'ємною складовою економічного і соціальнополітичного розвитку, прогресу суспільства i держави, а також якості життя.

Від освіченості й освіти (рівня i напряму) людини, залежить i культура (у т. ч. правова) суспільства. Правова культура це не лише знання та розуміння права, а також і свідомі дії відповідно до його вимог. 3 правової культури фізичної особи складається правова культура суспільства, яка посвідчує рівень правосвідомості та правової активності суспільства, ступінь прогресивності юридичних норм i правозастосування. Правова культура будь-якого (у т. ч. українського) суспільства також $є$ одним 3 показників рівня його розвитку, що перебуває у постійній динаміці і потребує планомірної, безупинної і цілеспрямованої діяльності щодо правового виховання та правової освіти. Зрештою, якість правової культури та правової освіти впливає на якість норм права і практики їх застосування.

Правовиховна робота об'єднує різноманітні форми, методи та засоби i спрямована на підвищення рівня правової культури, зміцнення професійної дисципліни та законності, піднесення правової активності особи. До класифікаційних ознак і форм правового виховання належать наступні [20, с. 61]: правова освіта (навчання); правова пропаганда [14, с. 38]; правова просвіта; правова агітація [14, с. 37]; форми правомірної соціально-активної діяльності; індивідуальна правовиховна робота; самовиховання та самоосвіта; правозастосовча (юридична) практика, у т. ч. у процесі виконання службових обов'язків [15, с. 193]. Заначимо, що не вся юридична діяльність є практичною (правозастосовчою), також можна виокремити сфери юридичної науки та освіти.

Окремо слід звернути увагу на важливість питань і проблем безпосередньо пов'язаних 3 інституційно-правовим забезпеченням одного з основоположних прав людини - права на виховання та освіту (в т. ч. правове), як на міжнародному (всесвітньому і регіональному), так i на національному рівнях. Наприклад, основоположними міжнародними інституційними основами означеної сфери стало заснування у 1988 р. під егідою Ради (колишньої Комісіі) ООН з прав людини [13; 16] і Комітету OОН 3 економічних, соціальних i культурних прав [2] мандату Спеціального доповідача 3 питання про право на освіту [9], а з поміж міжнародних нормативно-правових актів, можна виокремити наступні:

- загального, правовстановлюючого характеру: Загальна Декларація прав людини 1948 р. [1, ст. 26]; Міжнародний пакт про економічні, соціальні і культурні права 1966 р. [12, ст. ст. 13-14] та Факультативного протоколу до нього 2008 р., що фактично заснував процедуру розгляду скарг на порушення означених прав з боку держав-учасниць [18]; Конвенція про захист прав людини і основоположних свобод 1950 р. [4, ст. 2 Протоколу I]; Хартія основних прав ЄС 2000 р. [19; ст. 14]; 
- щодо окремих груп фізичних осіб: Конвенція про права дитини 1989 р. [6; ст. ст. 28-29]; Конвенція про права інвалідів 2006 р. [7; ст. 24] та Факультативний протокол до неї [17]; Міжнародна конвенція про захист прав всіх трудящих мігрантів та членів їх сімей 1990 р. [10, ст. 43];

- щодо подолання обмежень, у т. ч. деякими групами фізичних осіб: Конвенція про боротьбу з дискримінацією у сфері освіти 1960 р. [3, ст. ст. 3-4]; Міжнародна конвенція про ліквідацію всіх форм расової дискримінації 1965 р. [11, ст. 5]; Конвенція про ліквідацію всіх форм дискримінації щодо жінок 1979 р. [5, ст. 10] та ін.

Міжнародна нормативно-правова та інституційна база, мають здебільшого декларативний характер без дієвих національних механізмів їх реалізації і забезпечення. Нажаль, в українському суспільстві на буденному (побутовому) рівні сформоване нігілістичне відношення до права та його реалізації, що означає не лише заперечення права, як соціальної цінності в суспільстві, але і нешанобливе ставлення до нього, до діяльності будь-яких органів держави, у т. ч. судових і правоохоронних, або причетних осіб (наприклад, адвокатів, приватних нотаріусів, тощо). Причинами правового нігілізму можна вважати: правову недосвідченість громадян і посадових осіб; бажання обійти норми права для отримання переваг при мінімальних ризиках відповідальності; підрив довіри суспільства до «законодавця»; чисельність нормативно-правових актів i ïx нашарування, суперечливість у регулюванні одних і тих же питань, тощо. Можна погодитися [8, с. 109], що в результаті спостерігаються наступні види деформації правосвідомості: - правовий фетишизм (перебільшення, абсолютизація ролі і значення правового регулювання в житті суспільства); - правовий інфантилізм (недооцінка ролі права, недостатне знання права); переродження правосвідомості (через усвідомлене ігноруванні i запереченні закону і допустимість правопорушень). Наприклад, певний перекіс у побутовому сприйнятті застосування права, зокрема гарне знання фізичними особами своїх прав, нажаль не завжди їх відстоювання і захист, та суттєве ігнорування виконання своїх обов'язків, вкрай рідко внаслідок їх незнання.

Отже, існуючих інституційно-правових заходів правового виховання i правової освіти виявляється замало для повноцінного та стабільного розвитку правової культури суспільства. Необхідно приділяти значно більше уваги, в першу чергу, правовому вихованню, створювати заходи, які поширюватимуться на всі вікові та соціальні категорії населення, допомагатимуть оволодівати правовими знаннями, вчитися розуміти право та діяти відповідно до його вимог. В другу чергу, внаслідок прямого взаємозв'язку між глобалізацією і значенням освіти (зокрема, вищої) для особистого і суспільного зростання і процвітання, має відбуватися переоцінка $\mathrm{i}$ активне застосування міжнародних і національних 
інституційно-правових підвалин прав людини, зокрема на освіту різних рівнів, у т. ч. правову.

\section{Література:}

1. Загальна декларація прав людини: декларація ООН від 10.12.1948. URL: https://zakon.rada.gov.ua/laws/show/995_015\#Text (дата звернення: 19.04.2021).

2. Комітет $\mathrm{OOH} з$ економічних, соціальних і культурних прав. URL: https://www.ohchr.org/en/hrbodies/cescr/pages/cescrindex.aspx (дата звернення: 19.04.2021).

3. Конвенція про боротьбу 3 дискримінацією в галузі освіти: конвенція ООН від 14.12.1960. URL: https://zakon.rada.gov.ua/laws/ show/995_174\#Text (дата звернення: 19.04.2021).

4. Конвенція про захист прав людини і основоположних свобод: конвенція Ради Свропи від 04.11.1950, ETS № 005, в ред. від 02.10.2013. URL: https://zakon.rada.gov.ua/laws/show/995_004\#Text (дата звернення: 19.04.2021).

5. Конвенція про ліквідацію усіх форм дискримінації щодо жінок: конвенція ООН від 18.12.1979, в ред. від 06.10.1999. URL: https://zakon.rada.gov.ua/laws/show/995_207\#Text (дата звернення: 19.04.2021).

6. Конвенція про права дитини: конвенція ООН від 20.11.1989, в ред. від 20.11.2014. URL: https://zakon.rada.gov.ua/laws/show/995_021\#Text (дата звернення: 19.04.2021).

7. Конвенція про права осіб з інвалідністю: конвенція ООН від 13.12.2006. URL: https://zakon.rada.gov.ua/laws/show/995_g71\#Text (дата звернення: 19.04.2021).

8. Матузова Н. И., Малько А. В. Теория государства и права: курс лекций. М.: Юристъ, 2000. 761 с.

9. Мандат Спеціального доповідача з питання про право на освіту OOH. URL: https://www.ohchr.org/RU/Issues/Education/SREducation/Pages/ SREducationIndex.aspx (дата звернення: 19.04.2021).

10. Міжнародна конвенція про захист прав всіх трудящих мігрантів та членів їх сімей: конвенція ООН від 18.12.1990. URL: https://zakon.rada.gov.ua/laws/show/995_203\#Text (дата звернення: 19.04.2021).

11. Міжнародна конвенція про ліквідацію всіх форм расової дискримінації: конвенція ООН від 21.12.1965, в ред. від 04.02.1994. URL: https://zakon.rada.gov.ua/laws/show/995_105\#Text (дата звернення: 19.04.2021).

12. Міжнародний пакт про економічні, соціальні i культурні права: пакт ООН від 16.12.1966, в ред. від 19.10.1973. 
URL: https://zakon.rada.gov.ua/laws/show/995_042\#Text (дата звернення: 19.04.2021).

13. Органы ООН по правам человека. URL: http://www.ohchr.org/RU/ HRBodies/Pages/HumanRightsBodies.aspx (дата звернення: 19.04.2021).

14. Погребной И. М. Теория права : учебное пособие. 3-е изд., испр. и доп. Х.: Государственное специализированное издательство «Основа», 2003. $122 \mathrm{c.}$

15. Романов В. В. Юридическая психология: учебник. М.: Юристь, 1998. 488 с.

16. Рада ООН 3 прав людини. URL: https://www.ohchr.org/ EN/HRbodies/HRC/Pages/Home.aspx (дата звернення: 19.04.2021).

17. Факультативний протокол до Конвенції про права осіб 3 інвалідністю: протокол ООН від 13.12.2006, в ред. від 06.07.2016. URL: https://zakon.rada.gov.ua/laws/show/995_g72\#Text (дата звернення: 19.04.2021).

18. Факультативний протокол до Міжнародного пакту про економічні, соціальні і культурні права: протокол ООН від 10.12.2008. URL: https://zakon.rada.gov.ua/laws/show/995_i50\#Text (дата звернення: 19.04.2021).

19. Хартія основних прав Свропейського Союзу: хартія $\mathrm{CC} \mathrm{від}$ 07.12.2000. URL: https://zakon.rada.gov.ua/laws/show/994_524\#Text (дата звернення: 19.04.2021).

20. Черданцев А. Ф. Теория государства и права: учебник для ВУЗов. М.: Юрайт, 2002. 432 с.

DOI https://doi.org/10.30525/978-9934-26-074-2-3

\title{
РОЗГЛЯД СУДАМИ СПРАВ ПРО РОЗІРВАННЯ ШЛЮБУ У ЗАХІДНИХ ОБЛАСТЯХ УРСР В 1944-1953 РР.
}

\author{
Думанівська А. Я. \\ судовий розпорядник \\ Львівського окружного адміністративного суду \\ м. Львів, Україна
}

Відповідно до глави 26-а ЦПК 1929 р., до цивільних справ окремого провадження були віднесені справи про розірвання шлюбу. Окреме провадження передбачалось як безспірне провадження. Незважаючи на виділення в цивільному процесі окремого провадження як відносно самостійного, загальні для всіх справ окремого провадження норми, які регулювали б порядок їх розгляду, не були сформульовані [4, с. 34, 42]. 